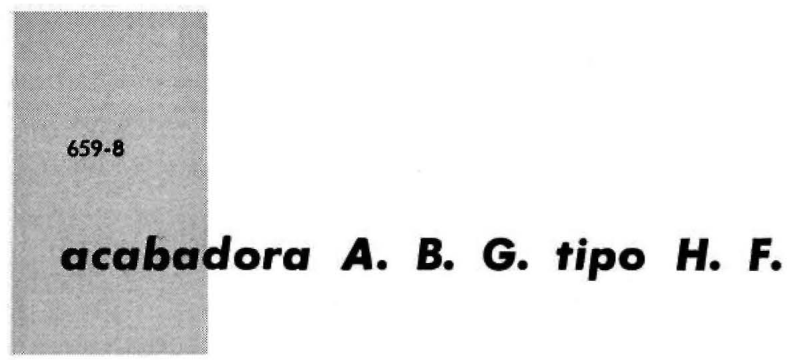

Esta máquina ligera posee características de trabajo comparables a las de máquinas superiores (logra compactaciones de espesores de hasta $400 \mathrm{~mm}$ en una sola pasada).

Sus elementos de trabajo pueden descender hasta $250 \mathrm{~mm}$ con el fin de poder compactar las capas inferiores, de grava, arena, etc.

El ancho de labor es variable entre 1,50 y $5 \mathrm{~m}$, y se garantiza una compactación uniforme de todas las partes y zonas de la franja de hormigón, por medio de la alta frecuencia de la viga vibradora.

No hay transmisiones de vibración al bastidor de la máquina ni encofrados. Al construir peraltes e inclinaciones laterales, la diferencia de elevación entre los encofrados se compensa con el ajuste del lado respectivo de la máquina.

\title{
Características mecánicas
}

Ajuste de elevación.-La elevación se regula de forma simple, por medio de una manivela, con pestillo de fijación, quedando visible en una escala graduada., La altura de reglaje es de $250 \mathrm{~mm}$, pudiendo variar la elevación de los elementos entre sí.

Tablón vibrante.-La frecuencia es de 2.900 r.p.m.

Motor-El motor y el embrague se encuentran en una bancada especial, protegida contra las sacudidas de la vibración por piezas de metal alástico interpuestas.

Propulsión.-Se efectúa por dos operarios que manejan los dos volantes laterales; el accionamiento del avance se lleva a cabo mediante transmisión de cadena subre ias cuatro ruedas.

Ruedas de pestaña.-Como solamente son precisas en un lado de la máquins, son intercambiables al lado opuesto, según el lado en que se encuentre el rail.

Dispositivo de transporte.-Sin pérdida de tiempo, se pueden fijar a la máquina una rueda directriz delantera y dos traseras. De esta manera puede ser remolcada por un camión sin ser necesarios vehículos especiales para ser trasladada.

M. CHINCHILLA

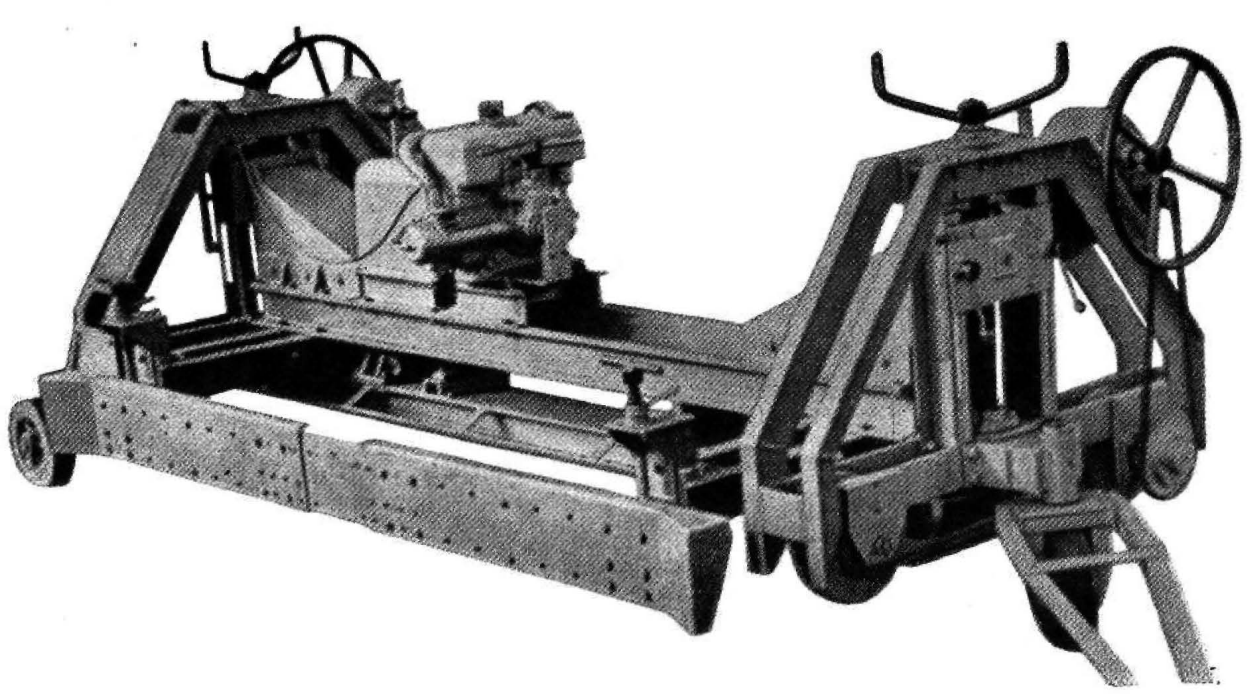

